\title{
SELECTION OF SALT TOLERANT CLONES OF SOME MEDICINAL PLANTS THROUGH TISSUE CULTURE TECHNIQUE:
}

I. Hyoscyamus muticus L. PLANT. Hanna, N.E.; K.M. El-Gamassy; A.M. Kandeel and Laila M. Helmy Hort. Dept., Fac. Agric., Ain shams Univ., Shoubra El-Keima, Cairo, Egypt.

\begin{abstract}
Response of Egyptian henbane plant callus (Hyoscyamus muticus L.) to various levels of salt was investigated. Two tolerant clones to salt were selected from callus cultured on selection medium contained 6000 and $8000 \mathrm{ppm}$ of salts, respectively. Tolerant clones were capable of proliferating and growing on media contained the same salt concentrations and supplemented with $1.5 \mathrm{ppm}$ of BA. Vegetative characters were significantly enhanced in general at the lower salt concentration (6000 ppm) especially with the media containing $0.12 \mathrm{~g} / \mathrm{L} \mathrm{KH}_{2} \mathrm{PO}_{4}+4$ ppm kinetin $+0.5 \mathrm{ppm}$ IBA. Using of MS media at its half strength with $1 \mathrm{ppm}$ NAA was the best for henbane root growth at $6000 \mathrm{ppm}$ of salt. Survival percentage reached up to $28.00 \%$ for clone $A$ (selected at $6000 \mathrm{ppm}$ ) and $32.02 \%$ for clone B(selected at $8000 \mathrm{ppm}$ ) with a total alkaloid percentage of 0.90 and $0.98 \%$, respectively .
\end{abstract}

Keywords: Salt tolerant clones - Tissue culture technique - Hyoscyamus muticus

\section{INTRODUCTION}

One of the most significant trends in plant biotechnology is to produce cultivars tolerant to unfavorable environmental conditions including salt stress.

However, only little success is attained using Conventional breeding methods for enhancing the response of plants to saline tension. Tissue culture techniques have widely been employed for production of plants bearing specific traits including disease resistance, cold tolerance and salt tolerance. The main idea of using tissue culture in a biotic experiments is based on the fact that cell is used as a selection unit instead of the whole plant. Various plant species have successfully been manipulated in vitro under salt strain conditions and finally salt - tolerant plants were recovered (Garcia - Reina, et al 1988 and Barakat and Abdelatif 1995).

Henbane is one of the most common plants in the family Solanaceae (Dhoot and Hpnshaw, 1977). The plant occurs in the desert in patches occupying depressions in sandy areas which receive runoff water. It grows in areas where the measured rainfall averages $20 \mathrm{~mm}$ or more per year. Water runoff increases the water revenue in habitats supporting the wild plant. However, the supply from wild plants is not sufficient for industrialization.

Due to the lack of available knowledge study the production of salt tolerant clone of henbane, this present work focuses on applying selection of salt - resistant cells of Hyoscyamus muticus callus cultures and forcing this selected callus to proliferate into shoots leaves and roots under the same levels of salts. The present work is based on many previous researchers 
whom have been working in this field of study using different techniques as Davis et al (1977) with his work on carnation, pointed out the role of using NAA at $1 \mathrm{ppm}$ and kinetin at $10 \mathrm{ppm}$ to improve the growth of carnation shoot tips. El-Tarras (1995) with Banana, declared the importance of using electrophoresis technique to diminish the possibility of deformed banana plantlets production. Maged (1996) with Cucumis melo, succeeded to produce a colne tolerant to sodium chloride from callus of Cantaloupe. Zhao et al (2001), mentioned the role of addition of $\mathrm{KCl}$, mannitol, and synthetic precursors and bioregulators on improving indole alkaloid production of Catharanthus roseus callus culture. Ouf et al (2003) with Sorghum bicolor, utilized the somaclonal variation tool to produce new high productive cultivars of sorghum. Al-Wasel ( 2006), studied the role of using growth regulators ( $B A, G A 3, I B A$, and IAA) on improving nodal segments growth, proliferation and rooting of Atropa belladonna plant.

It is hoped that this study will provide the necessary information for selection salt tolerant clones of henbane and for further investigations on understanding biological basis of salt resistance in plants.

\section{MATERIALS AND METHODS}

\section{1- Plant material}

Callus was initiated from mature seeds of Hyoscyamus muticus $\mathrm{L}$ obtained from the Experimental farm of Faculty of Pharmacy, Cairo University. The seeds were surface sterilized in commercial hypochlorite solution (Clorox) at concentration of $30 \%$ for $20 \%$ minutes, then washed three times with sterilized distilled water. Sterilized seeds were cultured onto surface of Murashige and Skoog media (1962). Twenty seeds had been cultured in each experimental $250 \mathrm{ml}$ jar. The medium was supplemented with Glycine $(1 \mathrm{mg} / \mathrm{L})$, Thiamine (1mg / L), Nicotinic acid (1mg/L), pyridoxine $(1 \mathrm{mg} / \mathrm{L})$, and Myo-Inositol ( $1 \mathrm{mg} / \mathrm{L})$. Growth regulators were added to the culture medium depending on the stage of culture as following:

\section{a) Callus initiation}

The media used for henbane callus initiation is based mainly on using MS medium supplemented with $2.5 \mathrm{ppm} \mathrm{GA}+2 \mathrm{ppm}$ CaPantothenic acid for all treatments except with control treatment.

The previous media composition was amended with the desired growth regulators under investigation as following :

$\mathrm{BA}$ at $0.5,1$ and $1.5 \mathrm{ppm}$.

2,4-D at 1 and $5 \mathrm{ppm}$.

$\mathrm{NAA}$ at 1 and $5 \mathrm{ppm}$.

B ) Callus Differentiation and proliferation

The medium used for callus proliferation was mainly MS media with $0.12 \mathrm{glL} \mathrm{KH} 2 \mathrm{PO} 4$ plus the growth regulators under investigations as following: Kinetin at $4 \mathrm{ppm}$ in combination with IBA at $0.5 \mathrm{ppm}$ or NAA at $0.5 \mathrm{ppm}$.

\section{C) Root growth} following:

Root growth has been studied using different types of media as 
- MS medium at full strength (control).

- MS medium at half strength. IBA at $1 \mathrm{ppm}$.

- MS medium at half strength supplemented with NAA at $1 \mathrm{ppm}$ or

Following adjustment of the $\mathrm{pH}$ at (5.8), $3 \%$ sucrose and $7 \mathrm{~g} / \mathrm{L}$ agar were added to the culture medium. The media were autoclaved for $20 \mathrm{~min}$ at 1.5 bars then kept in light at room temperature until use.

The whole work has been done at the experimental laboratory of tissue culture, Horticulture Department, Faculty of Agriculture, Ain Shams University, Shoubra El -Keima, Cairo, Egypt.

\section{D) Acclimatization}

Successful plantlets had been adapted to acclimatization stage using direct exposure of cultivated jars to normal environmental conditions for one week. The plantlets brought out the jars and washed to free them from medium's agar. Finally, the plantlets cultured in foam pots contain peat: sand at ratio of $1: 1$.

\section{2) Salt Selection procedures}

Inhibitory concentrations were determined by transferring small pieces of callus on surface of nutrient medium containing Sodium chloride, Magnesium chloride and Potassium chloride at the ratio of $[1 \mathrm{NaCl}: 3$ ( 1 $\mathrm{MgCl}: 3 \mathrm{KCl})$ ] and the salt concentrations of: 0, 2000, 4000, 6000, 8000 up to 16000ppm.

The cultures were incubated at $22{ }^{\circ} \mathrm{C} \pm 2{ }^{\circ} \mathrm{C}$ for 45 days. Callus fresh weight was determined according to Meredith (1978).

Having determined the lowest inhibitory concentrations selection was carried out using concentrations higher than that known to have inhibitory effect.

\section{3) Alkaloids content determination}

The total percentage of alkaloids content was determined using plantlets fresh leaves based on Atropine alkaloid determination method mentioned by Foster and Cornelia (1970).

\section{4) Statistical analysis}

The experiment has been designed using a complete randomized design with four replicates of each treatment and each replicate had four jars. Data were statistically analyzed according to Snedecor and Cochran (1967). Comparisons among means were made via the least significant difference multiple ranges (LSD) and Duncan student test.

\section{RESULTS AND DISCUSSION}

\section{- Growth of callus}

Callus initiation of henbane seeds was significantly enhanced by using BA compared with the other growth regulators have been investigated. 2,4-D and NAA had an effect on callus growth compared to the control treatment but without significance compared with the BA treatments as shown in Table(1).

It is evident that using MS media supplemented with BA at $1 \mathrm{ppm}$ in combination with GA at $2.5 \mathrm{ppm}$ and $\mathrm{CaPantothenic}$ acid at $2 \mathrm{ppm}$ gave a 
significant value of callus initiation (11.06 clone/ jar). The other BA concentrations ( 0.5 and $1.5 \mathrm{ppm}$ ), 2,4-D and NAA at various concentrations did not show a significant difference compared with the control.

These findings agree with those of Ghanem (1994) who stated that growth regulators plays an important role on the morphogenesis response in vitro of henbane plant due to their influence on cell division, cell elongation and enlargement.

Similar results had been mentioned also by Al-Wasel ( 2006), who used Murashige and Skoog media supplemented with BA at (0.5 - $2.5 \mathrm{ppm})$ to induce multiple shoot formation of Atropa belladonna L. plant

Table (1): Callus initiation four weeks after sowing under different MS media regimes supplemented with different growth regulators of Hyoscyamus muticus seeds

\begin{tabular}{|c|c|}
\hline Media type & $\begin{array}{l}\text { Callus initiation ( No } \\
\text { of clones per jar) }\end{array}$ \\
\hline Control ( MS media free of growth regulators)( &.,..$d$ \\
\hline $\mathrm{MS}+2.5 \mathrm{ppm}$ GA+2 ppm CaPantothenic acid+ $0.5 \mathrm{ppm} \mathrm{BA}$ & $V, r Y b$ \\
\hline $\mathrm{MS}+2.5 \mathrm{ppm} \mathrm{GA}+2 \mathrm{ppm} \mathrm{CaPantothenic} \mathrm{acid+1} \mathrm{ppm} \mathrm{BA}$ & $11, .4 \mathrm{a}$ \\
\hline $\mathrm{MS}+2.5 \mathrm{ppm} \mathrm{GA}+2 \mathrm{ppm}$ CaPantothenic acid+1.5 ppm BA & $9, \varepsilon \% \mathrm{ab}$ \\
\hline $\mathrm{MS}+2.5 \mathrm{ppm}$ GA+2 ppm CaPantothenic acid+ $1 \mathrm{ppm}$ 2,4D & $r, \ldots c$ \\
\hline $\mathrm{MS}+2.5 \mathrm{ppm}$ GA+2 ppm CaPantothenic acid+5 ppm 2,4D & $\varepsilon, \Gamma Y^{c}$ \\
\hline $\mathrm{MS}+2.5 \mathrm{ppm} \mathrm{GA}+2 \mathrm{ppm}$ CaPantothenic acid+1 ppm NAA & $r, 9 \mathrm{rc}^{2}$ \\
\hline $\mathrm{MS}+2.5 \mathrm{ppm}$ GA+2 ppm CaPantothenic acid+ 5 ppm NAA & $r$, rOC \\
\hline
\end{tabular}

Table (2) indicates the influence of direct exposure of callus portions to salt concentrations. Data clarifies the role of using the growth regulators to improve henbane cells tolerance to salts. Callus growth was significantly enhanced at the lower concentration of salt (4000 ppm) compared with the higher ones (6000 and $8000 \mathrm{ppm})$. Using of BA at $0.5 \mathrm{ppm}$ has a significant effect on callus growth reached up to 1.58 clones/ jar. However, the interaction of using BA at $0.5 \mathrm{ppm}$ with salts has the same trend of giving high significant values of callus growth at the lowest level of salt (4000 ppm).

Table (2): Hyoscyamus muticus callus growth under different salt concentrations and growth regulator treatments.

\begin{tabular}{|c|c|c|c|c|}
\hline Salt concentrations. & $\begin{array}{l}4000 \\
\text { ppm }\end{array}$ & $\begin{array}{l}6000 \\
\text { ppm }\end{array}$ & $\begin{array}{l}8000 \\
\text { ppm }\end{array}$ & Mean \\
\hline Media type. & \multicolumn{4}{|c|}{ Average number of clones/ jar } \\
\hline Control ( MS media) & $0.50^{\mathrm{c}}$ & $0.50^{\mathrm{c}}$ & $0.00^{\mathrm{c}}$ & $0.16^{d}$ \\
\hline $\mathrm{MS}+2.5 \mathrm{GA}+2 \mathrm{ppm}$ CaPantothenic acid + $0.5 \mathrm{ppm} \mathrm{BA}$ & $3.25^{a}$ & $1.50^{b}$ & $0.00^{c}$ & $1.58^{a}$ \\
\hline MS + 2.5 GA + 2 ppm CaPantothenic acid + 1 ppm BA & $3.25^{a}$ & $0.25^{c}$ & $0.00^{c}$ & $1.16^{b}$ \\
\hline $\mathrm{MS}+2.5 \mathrm{GA}+2 \mathrm{ppm}$ CaPantothenic acid + $1.5 \mathrm{ppm}$ BA & $1.25^{b}$ & $0.50^{\mathrm{c}}$ & $0.00^{c}$ & $0.66^{\mathrm{cd}}$ \\
\hline $\mathrm{MS}+2.5 \mathrm{GA}+2 \mathrm{ppm}$ CaPantothenic acid + $5 \mathrm{ppm} 2,4-\mathrm{D}$ & $0.25^{c}$ & $0.00^{\mathrm{c}}$ & $0.25^{c}$ & $0.33^{c}$ \\
\hline Mean & $1.75^{a}$ & $0.55^{b}$ & $0.05^{c}$ & \\
\hline
\end{tabular}

Table (3) data shows the effect of gradual exposure of successfully selected henbane callus clones on $4000 \mathrm{ppm}$ salt concentration. Clones selected at $4000 \mathrm{ppm}$ were cultured on media containing higher salt concentrations as following 8000,12000 , and $16000 \mathrm{ppm}$. 
J. Agric. Sci. Mansoura Univ., 34 (3), March, 2009 
Basically, callus clones grew well with MS media supplemented with 8000 ppm salts compared with the other higher concentrations, 12000 and 16000 ppm. Significant increases of number of callus clones per jar, callus fresh weight/g and callus dry weight/g have been achieved with the lowest salt concentration $(8000 \mathrm{ppm})$ and were $2.00,9.45$ and 2.09 respectively. Also using of growth regulators had a significant effect for different callus characters especially with adding BA to the medium at $0.5 \mathrm{ppm}$ plus $2.5 \mathrm{ppm}$ of GA and 2 ppm of CaPantothenic acid.

Concerning the interaction between it could be observed that salinity and media composition, the same trend has been observed concerning the role of growth regulators on improving callus capability for salt tolerance. The callus fresh weight has significantly enhanced by using BA at $0.5,1$, and 1.5 ppm with values of $11.12,10.27$, and $13.27 \mathrm{~g}$, respectively.

These findings may be attributed to the changes in the endogenous hormones in the cultured tissue as well as the influence of the period of culture (Murashige, 1977).

In this experiment, the same trend has been observed with proliferation of callus under different levels of salt.

The medium containing $1.5 \mathrm{ppm}$ BA in combination with $2.5 \mathrm{ppm}$ GA enhanced shoot proliferation compared with the other media contain Kinetin and/or IBA. The most significant effect induced by BA at the lower salt concentration (8000 ppm) as shown in Table (4).

Table (4) shows that increasing BA concentration to $1.5 \mathrm{ppm}$ significantly improves henbane callus proliferation to bud primorida with value reached up to 2.75 proliferated clones/ jar. BA was better than using Kinetin with various concentrations $(2,3$, and $5 \mathrm{ppm})$ mixed with IBA at $0.5 \mathrm{ppm}$. Generally, clones proliferation was significantly better at the lower salt concentration $(8000 \mathrm{ppm})$ compared with the higher ones. The same trend has been noticed concerning the interaction between growth regulators effect and salt as BA significantly improves callus proliferation with value of 5.31 proliferated clones/ jar.

Table (4): Callus proliferation six weeks after subdividing under different salt concentrations and growth regulator treatments of Hyoscyamus muticus plant.

\begin{tabular}{|c|c|c|c|c|}
\hline 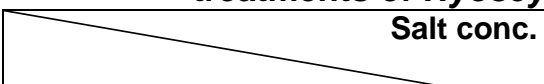 & $\begin{array}{l}8000 \\
\text { ppm }\end{array}$ & $\begin{array}{l}12000 \\
\text { ppm }\end{array}$ & $\begin{array}{c}16000 \\
\text { ppm }\end{array}$ & Mean \\
\hline Media type & \multicolumn{4}{|c|}{ Number of proliferated clones/ jar } \\
\hline MS media( control ) & $0.5^{\mathrm{de}}$ & $\cdot, 0 \mathrm{de}$ & $\cdot, \ldots \mathrm{e}$ & c \\
\hline $\begin{array}{l}\text { MS + } 2.5 \text { ppm GA + } 2 \text { ppm } \\
\text { Ca Pantothenic acid + } 1.5 \text { ppm BA }\end{array}$ & $0, r, a$ & $r, q \mu b$ & $\cdot, \ldots e$ & $r, v O a$ \\
\hline MS + 0.5 ppm IBA + 2 ppm Kinetin & $1.69^{\mathrm{c}}$ & $1.81^{\mathrm{c}}$ & $\cdot, \ldots e$ & $1,17 \mathrm{~b}$ \\
\hline MS + 0.5 ppm IBA + 3 ppm Kinetin & $1.06^{\mathrm{cd}}$ & $\cdot$, , I cde & $\cdot, \ldots e$ & $\cdot, 7 r_{c}$ \\
\hline MS + 0.5 ppm IBA + 5 ppm Kinetin & $3.13^{b}$ & $1,79 \mathrm{c}$ & $\cdot, \ldots \mathrm{e}$ & $1,7 \cdot b$ \\
\hline Mean & a & $1,00 \mathrm{~b}$ & $\cdot, \ldots \mathrm{c}$ & \\
\hline
\end{tabular}

- Vegetative growth

To evaluate the effect of two types of culture media on vegetative growth, several parameters were measured after six weeks of culture (Table 
5). Data obtained revealed that culture media containing IBA at $0.5 \mathrm{ppm}$ combined with $0.12 \mathrm{~g} / \mathrm{L} \mathrm{KH}_{2} \mathrm{PO}_{4}+4 \mathrm{ppm}$ kinetin showed better results of 2 $\mathrm{cm}$ plantlets, number of new shoots/plant, shoot length, average number of leaves and plant fresh and dry weights compared with the other medium contains NAA at $0.5 \mathrm{ppm}$ with the same media composition at the same lower salt level (6000 ppm).

It is noticeable that IBA was significantly better than NAA concerning most of estimated vegetative parameters. Number of new branches/ plantlet, shoot length/ cm, average leaf number/ jar, plantlet fresh weight/ $\mathrm{g}$ and plantlet dry weight/g have been significantly improved by using $0.5 \mathrm{ppm}$ IBA with values of $2.70,4.22,9.97,4.55$, and 1.02 , respectively. Despite the advantage of using IBA over NAA, the last growth regulator significantly improves number of $2 \mathrm{~cm}$. plantlets (11.03 and 10.07 plantlets with 6000 and $8000 \mathrm{ppm}$ of salts) compared with IBA (7.53 plantlets at $6000 \mathrm{ppm}$ of salts).

These results are well understood in respect of effect of growth regulators and their role in controlling shoot formation ( Torres, 1989).

\section{- Root growth}

Table (6) show that Henbane root growth was significantly better at the lower salt concentration (6000 ppm) compared with the higher one (8000 ppm).

The medium containing half strength of MS basal salts with $1 \mathrm{ppm}$ of NAA was the best for root growth under the lower concentration of salts (6000 ppm).

Although of using of MS media at its half strength significantly improves henbane root growth, the medium containing salt needed to be amended with growth regulators for better root growth.

Using of half strength MS media plus NAA or IBA at $1 \mathrm{ppm}$ each significantly improved root growth with the media contained $6000 \mathrm{ppm}$ of salts.

These results get a long with those of Lorz et al (1979). It could be the lower levels of nitrogenous salts in media suitable for root formation especially with the perennial woody plants.

\section{- Plant survival and their alkaloid content}

Table (7) indicates that acclimatization of henbane plants selected under different salt concentrtion over a long period could be achieved. Clone A (selected at $6000 \mathrm{ppm}$ of salts) and clone B (selected at $8000 \mathrm{ppm}$ of salts) showed highly significant values of survival plants $(28.00$ and $32.02 \%$, respectively) compared with control plants.

However, the total percentage of alkaloids decreased for both clones compared with the control treatment. 
Hanna, N.E. et al.

5

1876 
J. Agric. Sci. Mansoura Univ., 34 (3), March, 2009 6 
Table (7): Survival plants and alkaloids percentages of acclimatized clones of Hyoscyamus muticus.

\begin{tabular}{|l|c|c|}
\hline Clone & $\begin{array}{c}\text { Survival } \\
\text { percentage }\end{array}$ & $\begin{array}{c}\text { Alkaloids } \\
\text { percentage }\end{array}$ \\
\hline control & $r r, 1, \mathrm{~b}$ & $1,1 \cdot$ \\
\hline Clone 1 ( selected at $6000 \mathrm{ppm})$ & $r \Lambda, \ldots \mathrm{a}$ & $\cdot, 9 \cdot$ \\
\hline Clone 2 ( Selected at $8000 \mathrm{ppm})$ & $r r, r \varepsilon \mathrm{a}$ & $\cdot, 9 \wedge$ \\
\hline
\end{tabular}

Generally, in most plants propagated in vitro, success depends on proper explants selection, medium composition, and suitable procedure for transplanting and acclimatization.

Hence, the survival plants percentages were higher despite of the salt levels may be because of using special medium containing different types of growth regulators over a long period of time (Murashige, 1977).

\section{REFERENCES}

Al-Wasel, A. S. (2006). In vitro multiplication of Atropa belladonna L. using nodal segments. Alexandria Journal of Agricultural Research, 44:3, 263-274

Barakat, M. N. and T. H. Abdelatif ( 1995). In vitro selection for salt tolerant lines in Wheat I- Effect of salt on embryogenic cultures.Alex. J. Agric. Res. 40 (1): 77-95.

Davis, M. J., Ralph Baker, Joe J. Hanan (1977). Clonal multiplication of Carnation by micropropagation.J. Amer. Soc. Hort. Sci. 102(1):48-53.

Dhoot, G. K., and Hpnshaw, G. G. (1977). Organization and alkaloid production in tissue cultures of Hyoscyamus niger.Ann. Bot. 41, 943.

El-Tarras, A. E., F. A. Taha and S. A. Abd El-Wahab (1995). Somacolonal variation in micropropagated banana at biochemical and chromosomal levels.Bull. Fac. Agric. Uinv. Cairo, 46: 429-440.

Foster dee Snell and Cornelia T. Snell (1970). Colorimetric methods of analysis.Van NOSTRAND Reinhold Company, P: 431-433.

Garcia-Reina, G., Moreno, V. and Luque, A. (1988). Selection for $\mathrm{NaCl}$ tolerance in cell culture of three Canary Island tomato land races.Recovery of tolerant plantlets from $\mathrm{NaCl}$-tolerant cell strains.J. of Plant Physiology, 133: 1-6.Ghanem, S. A. (1994). In vitro propagation of HyoscyamusBull. Fac. Agri. Univ. Cairo, 64: 103-112.

Lorez, H., Wernicke, W. and Potrykus, I. (1979). Culture and plant regeneration of Hyoscyamus protoplasts.Planta Medica. 36, 21.

Maged Zaki (1996). In vitro selection and ultra structural characterization of salt-tolerant cells of Cantaloupe ( Cucumis melo)

Meredith, C. (1978). Response of cultured tomato cells to Aluminum.Plant Science Letters, 12: 17-24.

Murashige, T. (1977). Plant cell and organ culture as horticultural practices.Acta. Horti., 78: 17.

Murashige, T. and Skoog, F. (1962). A revised medium for rapid growth and bio assays with tobacco tissue culture.Physiol. Plant. 15: 473- 497. 
Ouf, A. A., Fayza, M. A. El-Taweel, and M. Z. Attalah (2003). Selection of high productive cell lines through someclonal variation of Sorghum bicolor L. Monch. ( Var. Tracy).J. Adv. Agric. Res., vol. 8 (2), p. 211226.

Snedecor, G. W. and W. G. Cochran (1967). Statistical methods. $6^{\text {th }}$ ed., lowa State Univ. Press, lowa, USA.

Torres, K. C. (1989). Tissue culture techniques for horticultural crops.AVI Book, New York, P. 26.

Zhao, J., Q. Hu. Y. Guo, and W. H. Zhu (2001). Effect of stress factors, bioregulators, and synthetic precursors on indole alkaloid production in compact callus clusters cultures of Catharanthus roseus.

Appl. Microbiol. Biotechnol., 55: 693-698.

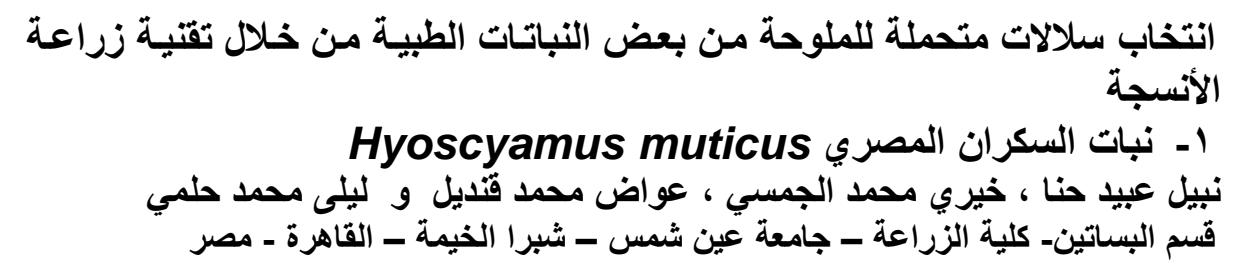

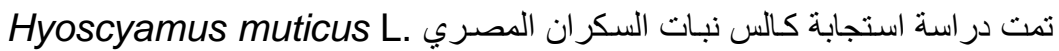

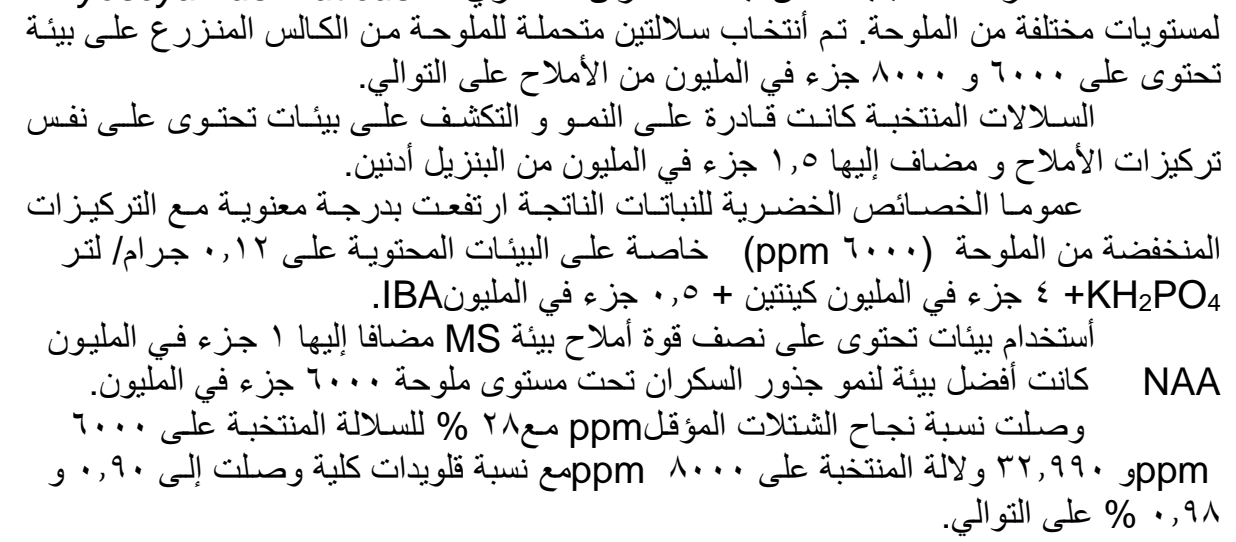


J. Agric. Sci. Mansoura Univ., 34 (3): 1869 - 1879, 2009

Table (3): Callus growth under different salt concentrations and growth regulator treatments of Hyoscyamus muticus plant.

\begin{tabular}{|c|c|c|c|c|c|c|c|c|c|}
\hline \multirow[b]{2}{*}{ Media type. } & \multicolumn{3}{|c|}{8000 ppm } & \multicolumn{3}{|c|}{12000 ppm } & \multicolumn{3}{|c|}{16000 ppm } \\
\hline & $\begin{array}{c}\text { No of } \\
\text { clones } \\
/ \text { jar }\end{array}$ & $\begin{array}{c}\text { Callus } \\
\text { fresh } \\
\text { weight/ } g\end{array}$ & $\begin{array}{c}\text { Callus } \\
\text { dry } \\
\text { weight / g }\end{array}$ & $\begin{array}{c}\text { No of } \\
\text { clones } \\
/ \text { jar }\end{array}$ & $\begin{array}{c}\text { Callus } \\
\text { Fresh } \\
\text { Weight / g }\end{array}$ & $\begin{array}{c}\text { Callus dry } \\
\text { weight } \\
/ g\end{array}$ & $\begin{array}{c}\text { No of } \\
\text { clones } \\
\text { / jar }\end{array}$ & $\begin{array}{c}\begin{array}{c}\text { Callus } \\
\text { fresh } \\
\text { weight/ }\end{array}\end{array}$ & $\begin{array}{l}\text { Callus dry } \\
\text { weight/ g }\end{array}$ \\
\hline \begin{tabular}{|c|} 
Control ( MS media) \\
\end{tabular} & $0.50 \mathrm{de}$ & $3.12^{\mathrm{b}}$ & $0.52^{\mathrm{e}}$ & 0.50 de & $3.02^{b}$ & 0.77 cde & $0.00^{\mathrm{e}}$ & $0.00^{\mathrm{e}}$ & $0.00^{\mathrm{e}}$ \\
\hline $\begin{array}{c}\text { MS + 2.5 GA + } 2 \mathrm{ppm} \mathrm{Ca} \\
\text { Pantothenic acid + 0.5 ppm BA }\end{array}$ & $3.75^{a}$ & $11.12^{a}$ & $2.85^{a}$ & $3.50^{\mathrm{a}}$ & $1.75^{b}$ & $0.06^{\mathrm{e}}$ & $0.75^{\text {cde }}$ & $4.37^{b}$ & $1.57 \mathrm{abcd}$ \\
\hline $\begin{array}{c}\text { MS + } 2.5 \mathrm{GA}+2 \mathrm{ppm} \mathrm{Ca} \\
\text { Pantothenic acid + } 1 \text { ppm BA }\end{array}$ & $2.25^{b}$ & $10.27^{a}$ & $2.32^{a b}$ & $3.75^{a}$ & $9.90^{a}$ & $1.50 \mathrm{bcd}$ & $0.00^{e}$ & $0.00^{e}$ & $0.00^{e}$ \\
\hline \begin{tabular}{|c|} 
MS + 2.5 GA + $2 \mathrm{ppm}$ \\
CaPantothenic acid + 1.5 ppm BA
\end{tabular} & $1.50 \mathrm{bcd}$ & $13.27^{a}$ & $2.67 \mathrm{ab}$ & $1.25^{b c}$ & $11.22^{a}$ & $1.97 \mathrm{abc}$ & $0.00^{\mathrm{e}}$ & $0.00^{\mathrm{e}}$ & $0.00^{\mathrm{e}}$ \\
\hline \begin{tabular}{|l|l|} 
Mean \\
\end{tabular} & $2.00^{a}$ & $9.45^{a}$ & $2.09^{a}$ & $2.37^{a}$ & $6.47^{b}$ & $1.07^{b}$ & $0.18^{b}$ & $1.09 \mathrm{c}$ & $0.39^{c}$ \\
\hline
\end{tabular}


Table (5): Vegetative growth of Hyoscyamus muticus plant as affected by different media types and salt concentration treatments.

\begin{tabular}{|c|c|c|c|c|c|c|c|c|c|c|c|c|}
\hline \multirow[t]{3}{*}{ Salt conc. } & \multicolumn{6}{|c|}{6000 ppm } & \multicolumn{6}{|c|}{8000 ppm } \\
\hline & \multicolumn{6}{|c|}{ Vegetative growth parameters } & \multicolumn{6}{|c|}{ Vegetative growth parameters } \\
\hline & $\begin{array}{c}\text { No. of } \\
2 \mathrm{~cm} \\
\text { plantlets }\end{array}$ & $\begin{array}{c}\text { No. of new } \\
\text { branches } \\
\text { /plant }\end{array}$ & $\begin{array}{c}\text { Shoot } \\
\text { length } \\
/ \mathrm{cm}\end{array}$ & $\begin{array}{c}\text { Average } \\
\text { leaf No. } \\
\text { /jar }\end{array}$ & \begin{tabular}{|c|}
$\begin{array}{c}\text { Plant } \\
\text { fresh } \\
\text { weight } \\
/ g\end{array}$ \\
\end{tabular} & $\begin{array}{c}\text { Plant dry } \\
\text { weight } \\
/ g\end{array}$ & $\begin{array}{c}\text { No. of } 2 \\
\text { cm } \\
\text { plantlets }\end{array}$ & $\begin{array}{c}\text { No. of new } \\
\text { branches } \\
\text { /plant }\end{array}$ & $\begin{array}{l}\text { Shoot } \\
\text { length / } \\
\text { cm }\end{array}$ & $\begin{array}{c}\text { Average } \\
\text { leaf No. } \\
\text { /jar }\end{array}$ & $\begin{array}{c}\text { Plant } \\
\text { fresh } \\
\text { weight } \\
\text { /g }\end{array}$ & $\begin{array}{c}\text { Plant dry } \\
\text { weight } \\
\text { /g }\end{array}$ \\
\hline $\begin{array}{c}\text { Control } \\
\text { (MS media) }\end{array}$ & $1.87^{\mathrm{c}}$ & $1.97^{a b}$ & $2.57^{\mathrm{b}}$ & $6.42^{b}$ & $3.27^{b}$ & $0.60^{b c}$ & $1.25^{\mathrm{c}}$ & $2.15 \mathrm{ab}$ & $1.55^{c}$ & $5.10^{b}$ & $2.22^{\mathrm{c}}$ & $0.60^{b c}$ \\
\hline $\begin{array}{c}\text { Control media }+0.12 \mathrm{~g} / \mathrm{L} \\
\mathrm{KH}_{2} \mathrm{PO}_{4}+4 \mathrm{ppm} \text { Kinetin } \\
+0.5 \mathrm{ppm} \text { IBA }\end{array}$ & $7.53^{b}$ & $2.70^{a}$ & $4.22^{a}$ & $9.97^{\mathrm{a}}$ & $4.55^{\mathrm{a}}$ & $1.02^{\mathrm{a}}$ & $6.56^{b}$ & $2.40^{\mathrm{ab}}$ & $2.15^{b c}$ & $9.20^{a}$ & $3.70^{a b}$ & $0.95^{a b}$ \\
\hline $\begin{array}{c}\text { Control media }+0.12 \mathrm{~g} / \mathrm{L} \\
\mathrm{KH}_{2} \mathrm{PO}_{4}+4 \mathrm{ppm} \text { Kinetin + } \\
0.5 \mathrm{ppm} \text { NAA }\end{array}$ & $11.03^{a}$ & $1.55^{b}$ & $2.02^{\mathrm{bc}}$ & $2.92^{c}$ & $2.92^{c}$ & $0.16^{d}$ & $10.07^{a}$ & $0.37^{c}$ & $1.82^{b c}$ & $2.97^{c}$ & $2.97^{c}$ & $0.25^{\mathrm{cd}}$ \\
\hline
\end{tabular}


Table (6): Root growth of Hyoscyamus muticus plant as affected by different media types and salt concentration treatments.

\begin{tabular}{|c|c|c|c|c|c|c|c|c|}
\hline \multirow{3}{*}{\begin{tabular}{|c|} 
Salt conc. \\
\end{tabular}} & \multicolumn{4}{|c|}{$6000 \mathrm{ppm}$} & \multicolumn{4}{|c|}{8000 ppm } \\
\hline & \multicolumn{4}{|c|}{ Root growth parameters } & \multicolumn{4}{|c|}{ Root growth parameters } \\
\hline & $\begin{array}{c}\text { Average No. } \\
\text { of roots }\end{array}$ & $\begin{array}{l}\text { Average } \\
\text { length of } \\
\text { roots } / \mathrm{cm}\end{array}$ & $\begin{array}{c}\text { Root } \\
\text { fresh } \\
\text { weight } / g\end{array}$ & $\begin{array}{l}\text { Root dry } \\
\text { weight } / g\end{array}$ & $\begin{array}{l}\text { Average No. } \\
\text { of roots }\end{array}$ & $\begin{array}{l}\text { Average } \\
\text { length of } \\
\text { roots } / \mathrm{cm}\end{array}$ & $\begin{array}{l}\text { Root fresh } \\
\text { weight } / g\end{array}$ & $\begin{array}{l}\text { Root dry } \\
\text { weight /g }\end{array}$ \\
\hline $\begin{array}{c}\text { Control } \\
\text { ( MS media) }\end{array}$ & 5.82 de & $2.10^{d}$ & $4.05^{\mathrm{e}}$ & $0.06^{d}$ & $9.15^{\mathrm{cd}}$ & $6.12^{a b c}$ & $7.15^{\mathrm{cd}}$ & $0.75^{\mathrm{b}}$ \\
\hline $\begin{array}{l}\text { MS media half } \\
\text { strength }\end{array}$ & $4.05^{\mathrm{e}}$ & $0.82^{d}$ & $4.72^{\mathrm{e}}$ & $0.11^{d}$ & $8.27^{\mathrm{cd}}$ & $4.77^{c}$ & 5.22 de & $0.57 \mathrm{bcd}$ \\
\hline $\begin{array}{c}\text { MS media half } \\
\text { strength }+1 \text { ppm NAA }\end{array}$ & $15.75^{a}$ & $7.67^{a}$ & $11.30^{a}$ & $1.85^{\mathrm{a}}$ & $8.92^{\mathrm{cd}}$ & $7.22^{a}$ & $5.57 \mathrm{de}$ & $0.20^{\mathrm{cd}}$ \\
\hline $\begin{array}{c}\text { MS media half } \\
\text { strength }+1 \mathrm{ppm} \text { IBA }\end{array}$ & $16.05^{a}$ & $7.77^{a}$ & $9.60^{a}$ & $1.00^{b}$ & $10.15^{b c}$ & $4.47^{c}$ & $3.55^{\mathrm{e}}$ & $0.67^{b c}$ \\
\hline $\begin{array}{c}\text { MS media half } \\
\text { strength }+5 \text { ppm NAA }\end{array}$ & $11.40^{b c}$ & $5.45^{b c}$ & $7.10^{\mathrm{cd}}$ & $1.00^{b}$ & $15.72 \mathrm{ab}$ & $6.65^{a b}$ & $8.80 \mathrm{bc}$ & $0.82^{b}$ \\
\hline $\begin{array}{c}\text { MS media half } \\
\text { strength }+5 \mathrm{ppm} \text { IBA }\end{array}$ & 7.52 cde & $4.32 \mathrm{c}$ & $5.40 \mathrm{de}$ & $0.65^{b c}$ & $13.72^{a b}$ & $5.02^{b c}$ & $7.30^{\mathrm{cd}}$ & $0.75^{\mathrm{b}}$ \\
\hline
\end{tabular}

